\title{
Association between the Methylation of CpG Islands in JAK-STAT Pathway-Related Genes and Colorectal Cancer
}

Rui Pu

Harbin Medical University

Hongru Sun

Harbin Medical University

Yupeng Liu

Harbin Medical University

Tian Tian

Harbin Medical University

Haoran Bi

Harbin Medical University

Tingting Xia

Harbin Medical University

Lei Zhang

Harbin Medical University

Yuanyuan Zhang

Harbin Medical University

Lin Zhu ( $\square$ zhulin095425@sina.com )

Harbin Medical University https://orcid.org/0000-0002-4779-4149

Jiesheng Rong

Harbin Medical University

Yashuang Zhao

Harbin Medical University

Primary research

Keywords: Methylation; JAK-STAT; Peripheral blood; Colorectal cancer; Interactive effect

Posted Date: July 30th, 2020

DOI: https://doi.org/10.21203/rs.3.rs-49979/v1 
License: (c) (i) This work is licensed under a Creative Commons Attribution 4.0 International License. Read Full License 


\section{Abstract}

Background: The Janus kinase-signal transducer and activator of transcription (JAK-STAT) pathway is involved in a series of biological processes. Aberrant promoter methylation of $\mathrm{CpG}$ islands plays an important role in carcinogenesis. However, the association between the DNA methylation of JAK-STAT pathway-related genes in peripheral blood leukocytes and colorectal cancer (CRC) susceptibility remains unclear.

Methods: We conducted a case-control study of 403 patients with CRC and 419 cancer free controls, and the DNA methylation levels of four genes (JAK2, STAT1, STAT3, and SOCS3) in peripheral blood samples from all subjects were assessed using a methylation-sensitive high-resolution melting (MS-HRM) analysis.

Results: Compared with controls, the methylation of the JAK2, STAT1 and SOCS3 genes significantly increased the $C R C$ risk $\left(\mathrm{OR}_{\text {adjusted }}=1.96,95 \% \mathrm{Cl}, 1.12-3.41, P=0.01 ; \mathrm{OR}_{\text {adjusted }}=5.37,95 \% \mathrm{Cl}, 3.74-7.71\right.$, $P<0.01 ; \mathrm{OR}_{\text {adjusted }}=3.30,95 \% \mathrm{Cl}, 1.58-6.87, P<0.01$, respectively). This trend was also found via stratified analysis. In the multiple CpG site methylation (MCSM) analysis, a high MCSM value denoted a significantly increased risk of $\mathrm{CRC}\left(\mathrm{OR}_{\text {adjusted }}=4.97,95 \% \mathrm{Cl}, 3.34-7.37, P<0.01\right)$. Antagonistic interactions were identified between the methylation of JAK2, STAT1 and high levels of MCSM and environmental factors with CRC risk $(P<0.05)$.

Conclusion: In peripheral blood, the methylation statuses of JAK2, STAT1, and high levels of MCSM, which are promising biomarkers, were significantly associated with CRC risk. An interaction between gene methylation and environmental factors contributed to the risk of CRC.

\section{Introduction}

As one of the most common digestive system cancers, colorectal cancer (CRC) has a high incidence of $1,849,518$ cases and 880,793 deaths worldwide in 2018[1]. The incidence is the third highest in males and second highest in females. CRC results from an accumulation of genetic and epigenetic changes. Aberrant methylation of $\mathrm{CpG}$ islands acts as a unique molecular mechanism in this process[2], which leads to oncogene activation and the inactivation of tumor suppressor genes[3]. DNA methylation of gene promoters always results in reduced or silenced expression of the target gene by inhibiting the recognition and binding of transcription factors to DNA[4].

The Janus kinase-signal transducer and activator of transcription (JAK-STAT) pathway rapidly transduces extracellular signals to the nucleus and regulate a series of biological processes, including proliferation, differentiation, apoptosis and immune reactions as well[5]. The pathway is composed of three components, Janus kinase (JAK), a transcription factor (STAT) and tyrosine kinase related receptors. JAK, a member of a class of non-receptor tyrosine kinases, includes four family members, JAK1, JAK2, JAK3 and TYK2, which are activated by a tyrosine kinase receptor. STATs are an important class of transcription factors that comprise a family of seven structurally and functionally related 
proteins: STAT1, STAT2, STAT3, STAT4, STAT5a, STAT5b, and STAT6. When specific extracellular signal factors, bind tyrosine kinase receptors, receptor-coupled JAKs are activated by phosphorylation. The phosphorylated tyrosine residues on the receptor and its surrounding amino acid sequences form a binding site that contains the $\mathrm{SH} 2$ domain, which recruits STATs in the cytoplasm as monomers. JAKs further phosphorylate STAT molecules coupled with receptors. Additionally, suppressors of cytokine signaling (SOCS) negatively modulate the JAK-STAT pathway by directly blocking the activation of the signaling pathway through the binding to phosphorylated JAK[5, 6].

JAK-STAT was shown to be constitutively activated in colorectal cancer tumor tissues, but not in normal epithelial tissue[7-9]. On the other hand, once the JAK-STAT pathway is inhibited, the expression of downstream anti-apoptotic proteins is downregulated, thus inhibiting tumor cell growth in CRC[7, 8, 10, 11]. We focused on four genes in the JAK-STAT pathway that may exert effects on CRC initiation and progression. JAK2 and phospho-JAK2 are present at higher levels in colon adenomas than in the normal colonic mucosa. Additionally, disruption of JAK2 and STAT3 signaling inhibits colorectal cancer cell invasion[12]. Meanwhile, the concomitant absence of STAT1 and STAT3 is significantly correlated with a poor overall survival of CRC patients[13]. SOCS3 inhibits the proliferation, migration, invasion and tumorigenic ability of CRC cells and accelerates cell apoptosis[14]. Abnormal methylation of CpG islands inhibits the recognition and binding of transcription factors to the DNA, thus inhibiting gene transcription and resulting in reduced expression or the absence of the relevant protein.

To date, most researchers have restricted their studies of the relationship between the methylation status of JAK-STAT pathway-related genes and risk of CRC to in vitro experiments and tumor tissues[15, 16]. Methylation of peripheral blood-derived DNA is related to the occurrence of tumors, and individual differences in methylation can reflect an individual's susceptibility to tumors $[17,18]$. In addition, it is reported that the effect of environmental factors on methylation status also found in peripheral blood and environmental factors contribute to CRC risk. Therefore, we conducted this case-control study to investigate the association between leukocyte-derived methylation of the JAK2, STAT1, STAT3, and SOCS3 genes in the JAK-STAT pathway in peripheral blood and CRC risk in Northeast China. We also assessed the interactive effects between environmental factors and these leukocyte-derived methylation events on the risk of CRC.

\section{Materials And Methods}

\section{Study Population}

Four hundred three patients with primary sporadic CRC who were diagnosed using postoperative pathology were recruited from the First and Second Affiliated Hospitals and the Cancer Hospital of Harbin Medical University. Patients with benign tumors, metastatic or recurrent colorectal carcinoma, adenomatous polyposis of the colon, gastrointestinal stromal tumors, or with a strong family history of CRC according to the Amsterdam criteria were excluded. 
Four hundred nineteen contemporaneous cancer-free controls were recruited from the Departments of Orthopedics and Ophthalmology at the Second Affiliated Hospital of Harbin Medical University. Based on the responses to the interview questions, controls with a history of gastrointestinal disease, severe organic disease or any cancers were excluded.

Before disposal, samples of venous blood $(5 \mathrm{~mL})$ were collected, conveyed to the laboratory in portable cold box to subpackage, and then stored at $-80^{\circ} \mathrm{C}$. Each participant completed a face-to-face interview with experienced interviewers to avoid bias as much as possible. The questionnaire was designed methodically and mainly collected demographic data (such as name, gender, age, address, level of education, and occupation) dietary habits (such as types of food, quantities and frequencies consumed in the past one year), lifestyle (such as medicine use, models of exercise, and tobacco and alcohol habits) and a family history of diseases. We conducted this study in accordance with the Declaration of Helsinki. All the participants provided informed consent before blood collection and the survey.

\section{Genomic DNA Extraction and Sodium Bisulfite Conversion}

Genomic DNA was extracted from 822 blood samples using the QIAamp DNA Blood Mini kit (Qiagen, Hilden, Germany) and quantified using a Nanodrop 2000 spectrophotometer (Thermo Scientific). Bisulfite conversion was performed using $2 \mu \mathrm{g}$ of DNA and an EpiTect Fast Bisulfite Kit (Qiagen, Hilden, Germany) according to the manufacturer's protocols. The transformed DNA was stored at $-20^{\circ} \mathrm{C}$.

\section{Methylation-Sensitive High-Resolution Melting (MS-HRM) Assays}

MS-HRM was performed on a LightCycler 480 machine (Roche Applied Science, Mannheim, Germany) equipped with Gene Scanning software (version 2.0) to detect the methylation status of four JAK-STAT pathway-related genes. Polymerase chain reaction (PCR) comprised a mixture of $0.6 \mu \mathrm{L}$ of bisulfitetreated DNA (12 ng), $0.25 \mu \mathrm{L}$ of each forward and reverse primer $(10 \mathrm{mM}), 5 \mu \mathrm{L}$ of LightCycler 480 High Resolution Melting Master Mix (Roche), $1.4 \mu \mathrm{L} \mathrm{MgCl}_{2}(25 \mathrm{mM})$ and $2.5 \mu \mathrm{L}$ of polymerase chain reaction PCR-grade water in a $10 \mu \mathrm{L}$ volume in a 96-well plate. Commercially available human whole genomic methylated and unmethylated DNA samples (Zymo Research) were prepared as a set of standards $(100 \%, 5 \%, 2 \%, 1 \%$, and $0 \%)$ and used to semi-quantitatively measure methylation levels in the samples.

Additionally, DNA-free water was used as a blank control in each plate and all reactions were performed in duplicate for quality control. Two investigators independently assessed the melting curves, and a third investigator joined the discussion if disagreements existed.

\section{Statistical Analysis}

The distributions of the characteristics and clinical data from patients and controls were tested using Student's T-test and Chi-square test for continuous variables and categorical variables, respectively. We conducted univariate and multivariate unconditional logistic regression analyses to calculate odds ratios 
(ORs) and 95\% confidence intervals (Cls), which estimated the associations between risk factors and CRC. Analyses of interactions between DNA methylation and environmental factors (including some dietary variables, such as coarse grain intake, and lifestyle factors, such as smoking) on the risk of CRC were examined using a crossover method and multivariate logistic regression analyses.

All statistical analyses were performed using IBM SPSS Statistics software, version 23.0. The reported $P$ values were two-sided, and $P<0.05$ was considered significant.

\section{Results}

\section{Characteristics of Subjects}

The study included 403 patients ( 156 females and 247 males) and 419 cancer free controls ( 201 females and 218 males), with significant differences in the mean age ( $59.51 \pm 11.37$ vs. $58.07 \pm 10.86, P=0.02)$. The distribution of overweight individuals (body mass index $[\mathrm{BMI}] \geq 23.00 \mathrm{~kg} / \mathrm{m}^{2}$ ) in the patient group was lower than in the control group $(52.51 \%$ vs. $64.05 \%, P<0.01)$. A lower proportion of patients had completed their education to a level greater than high school than the controls $(18.49 \%$ vs. $26.98 \%$, $P<0.01)$ and the percentage of white collar jobs among patients was less than controls $(8.15 \% \mathrm{vs}$. 18.98\%) (Table 1).

TABLE 1 Basic Demographic Characteristics of Patients and Controls

\begin{tabular}{|c|c|c|c|c|}
\hline Characteristics & & $\begin{array}{c}\text { Number of } \\
\text { Cases (\%) } \\
(n=403) \\
\end{array}$ & $\begin{array}{c}\text { Number of } \\
\text { Controls }(\%) \\
(\mathrm{n}=419)\end{array}$ & $P$ value \\
\hline \multirow[t]{2}{*}{ Gender } & Male & $247(61.29)$ & $218(52.03)$ & $<0.01$ \\
\hline & Female & 156(38.71) & 201(47.97) & \\
\hline \multicolumn{5}{|l|}{ Age (years)* } \\
\hline & Mean(SD) & 59.51(11.37) & $58.07(10.86)$ & 0.02 \\
\hline & $\leq 50$ & 69(18.06) & 88(21.00) & 0.09 \\
\hline & $50-$ & $121(31.68)$ & $135(32.22)$ & \\
\hline & $60-$ & $106(27.75)$ & $130(31.03)$ & \\
\hline & $\geq 70$ & $86(22.51)$ & $66(15.75)$ & \\
\hline \multirow[t]{4}{*}{ BMI $\left(\mathrm{kg} / \mathrm{m}^{2}\right) \# *$} & $\leq 18.50$ & $33(8.29)$ & $19(4.65)$ & $<0.01$ \\
\hline & $18.5-$ & 156(39.20) & $128(31.30)$ & \\
\hline & $\geq 23.00$ & $209(52.51)$ & $262(64.05)$ & \\
\hline & No Formal & & & \\
\hline \multirow[t]{5}{*}{ Education* } & Education & 107(29.97) & $79(19.04)$ & $<0.01$ \\
\hline & Primary & 104(29.13) & $115(27.71)$ & \\
\hline & Junior & $80(22.41)$ & $109(26.27)$ & \\
\hline & $\begin{array}{l}\text { Senior and } \\
\text { above }\end{array}$ & 66(18.49) & $112(26.98)$ & \\
\hline & White Color & & & \\
\hline \multirow[t]{2}{*}{ Occupational* } & Jobs & $30(8.15)$ & 78(18.98) & $<0.01$ \\
\hline & Others & 338(91.85) & $333(81.02)$ & \\
\hline
\end{tabular}

\#BMI: reference to Asia standard. 
*Age: 21 missing data; BMI: 15 missing data; Education: 50 missing data; Occupation: 43 missing data.

\section{DNA Methylation Status of Genes and CRC Risk}

Of the 4 genes, CRC risk was significantly correlated with the methylation of JAK2, STAT1 and SOCS3 (Table 2). After adjusting for gender, age, BMl, education and occupation, statistically significant associations between the methylation of these three genes and the risk of CRC were observed $\left(\mathrm{OR}_{\text {adjusted }}=1.96,95 \% \mathrm{Cl}, 1.12-3.41, P=0.01\right.$ for $J A K 2 ; \mathrm{OR}_{\text {adjusted }}=5.37,95 \% \mathrm{Cl}, 3.74-7.71, P<0.01$ for STAT1; $\mathrm{OR}_{\text {adjusted }}=3.30,95 \% \mathrm{Cl}, 1.58-6.87, P<0.01$ for SOCS3). However, for STAT3, a significant difference in methylation was not observed between patients and the controls, regardless of the adjustment (Table 2).

TABLE 2 Associations between the Methylation of Individual Genes and CRC Risk

\begin{tabular}{|c|c|c|c|c|c|c|c|}
\hline Genes & & Cases No. (\%) & Controls No.(\%) & OR $(95 \% \mathrm{CI})$ & $P$ value & $\mathrm{OR}_{\mathrm{ad}}(95 \% \mathrm{CI})$ & $P$ value \\
\hline \multirow[t]{2}{*}{$J A K 2$} & Negative & $297(87.61 \%)$ & $323(92.55 \%)$ & Ref & & Ref & \\
\hline & Positive & $42(12.39 \%)$ & $26(7.45 \%)$ & $1.76(1.05-2.94)$ & 0.03 & $1.96(1.12-3.41)$ & 0.01 \\
\hline \multirow[t]{2}{*}{ STAT1 } & Negative & $128(31.76 \%)$ & $295(75.84 \%)$ & Ref & & Ref & \\
\hline & Positive & $211(62.24 \%)$ & $94(24.16 \%)$ & $5.17(3.76-7.12)$ & $<0.01$ & $5.37(3.74-7.71)$ & $<0.01$ \\
\hline \multirow[t]{2}{*}{ STAT3 } & Negative & $299(90.88 \%)$ & $350(94.09 \%)$ & Ref & & Ref & \\
\hline & Positive & $30(9.12 \%)$ & $32(5.91 \%)$ & $1.10(0.65-1.85)$ & 0.73 & $0.99(0.57-1.72)$ & 0.56 \\
\hline \multirow[t]{2}{*}{ SOCS3 } & Negative & $11(3.38 \%)$ & $42(11.23 \%)$ & Ref & & Ref & \\
\hline & Positive & $315(96.62 \%)$ & $332(88.77 \%)$ & $3.62(1.83-7.16)$ & $<0.01$ & $3.30(1.58-6.87)$ & $<0.01$ \\
\hline \multirow[t]{2}{*}{ MCSM } & Low-level & $68(29.2 \%)$ & $210(69.1 \%)$ & Ref & & Ref & \\
\hline & High-level & $165(70.8 \%)$ & $94(30.9 \%)$ & $5.43(3.73-7.87)$ & $<0.01$ & 4.97(3.34-7.37) & $<0.01$ \\
\hline
\end{tabular}

CI: confidence interval; CRC: colorectal cancer; OR: odds ratio. $\mathrm{OR}_{\mathrm{ad}}$ adjusted for gender, age, BMI, education and occupation.

\section{MCSM Methylation Status and CRC Risk}

Among the 233 patients and 304 controls included in the present study, 2 patients and 20 controls did not display methylation of the four genes, 66 patients and 190 controls showed methylation of one gene, 136 patients and 71 controls showed methylation of two genes, 28 patients and 21 controls showed methylation of three genes, and 1 patient and 2 controls showed methylation of all four genes. The 527 results were integrated into a multiple CpG site methylation (MCSM) panel. We defined no or one methylation event as a low level of MCSM in the four genes; likewise, two, three or four methylation events were defined as a high level of MCSM.

After adjustments, a high MCSM level was associated with an increased risk of $\mathrm{CRC}\left(\mathrm{OR}_{\text {adjusted }}=4.97\right.$, $95 \% \mathrm{Cl}, 3.34-7.37, P<0.01$ for the high MCSM level). The details are shown in Table 2.

\section{Stratified Analysis}


In male, after adjusting above confounders, the methylation of STAT1 and SOCS3 significantly increased the risk of $\mathrm{CRC}\left(\mathrm{OR}_{\text {adjusted }}=2.46,95 \% \mathrm{Cl}, 1.73-4.39, P<0.01\right.$ and $\mathrm{OR}_{\text {adjusted }}=3.60,95 \% \mathrm{Cl}, 1.40-9.25, P<0.01$, respectively). In female, compared with the methylation-negative subjects, subjects with JAK2 and STAT1 methylation displayed a higher risk of $\mathrm{CRC}\left(\mathrm{OR}_{\text {adjusted }}=2.76,95 \% \mathrm{Cl}, 1.01-7.54 P=0.05\right.$, and $\mathrm{OR}_{\text {adjusted }}=14.05,95 \% \mathrm{Cl}, 7.50-26.34, P<0.01$, respectively) (Table 3a).

TABLE 3a Associations between the Methylation of Individual Genes and CRC Risk in Groups Stratified by Gender

\begin{tabular}{|c|c|c|c|c|c|c|}
\hline & Genes & & $\begin{array}{l}\text { Cases No. } \\
(\%)\end{array}$ & $\begin{array}{l}\text { Controls No. } \\
(\%)\end{array}$ & $\begin{array}{l}\mathrm{OR}_{\mathrm{ad}} \\
(95 \% \mathrm{CI})\end{array}$ & $P$ value \\
\hline \multirow[t]{8}{*}{ male } & $J A K 2$ & Negative & 178(86.4\%) & $167(90.8 \%)$ & Ref & \\
\hline & & Positive & $28(13.6 \%)$ & $17(9.2 \%)$ & $1.75(0.89-3.42)$ & 0.10 \\
\hline & STAT1 & Negative & 108(53.2\%) & 155(78.3\%) & Ref & \\
\hline & & Positive & $95(46.8 \%)$ & $43(21.7 \%)$ & $2.46(1.73-4.39)$ & $<0.01$ \\
\hline & STAT3 & Negative & 175(89.3\%) & 183(92.0\%) & Ref & \\
\hline & & Positive & $21(10.7 \%)$ & $16(8.0 \%)$ & $1.36(0.66-2.79)$ & 0.40 \\
\hline & SOCS3 & Negative & $7(3.4 \%)$ & $23(11.6 \%)$ & Ref & \\
\hline & & Positive & 196(96.6\%) & 175(88.4\%) & $3.60(1.40-9.25)$ & 0.01 \\
\hline \multirow[t]{8}{*}{ female } & $J A K 2$ & Negative & $119(89.5 \%)$ & $156(94.5 \%)$ & Ref & \\
\hline & & Positive & $14(10.5 \%)$ & $9(5.5 \%)$ & $2.76(1.01-7.54)$ & 0.05 \\
\hline & STAT1 & Negative & $20(14.7 \%)$ & $140(73.3 \%)$ & Ref & \\
\hline & & Positive & $116(85.3 \%)$ & $51(26.7 \%)$ & $14.05(7.50-26.34)$ & $<0.01$ \\
\hline & STAT3 & Negative & $124(93.2 \%)$ & 167(91.3\%) & Ref & \\
\hline & & Positive & $9(6.9 \%)$ & $16(8.7 \%)$ & $0.55(0.22-1.40)$ & 0.56 \\
\hline & SOCS3 & Negative & $4(3.3 \%)$ & $19(10.8 \%)$ & Ref & \\
\hline & & Positive & 117(96.7\%) & $157(89.2 \%)$ & $2.97(0.91-9.66)$ & 0.07 \\
\hline
\end{tabular}

CI: confidence interval; CRC: colorectal cancer; OR: odds ratio.

$\mathrm{OR}_{\mathrm{ad}}$ adjusted for age, BMI, education and occupation.

In the younger (age<60 years) group, STAT1 and SOCS3 methylation were associated with increased risks of $\mathrm{CRC}\left(\mathrm{OR}_{\text {adjusted }}=7.19,95 \% \mathrm{Cl}, 4.18-12.37, P<0.01\right.$, and $\mathrm{OR}_{\text {adjusted }}=2.78,95 \% \mathrm{Cl}, 1.05-7.34, P=0.04$, respectively). In the senior age (age $\geq 60$ years) group, associations between the methylation of the JAK2, STAT1 and SOCS3 genes and CRC risk were observed $\left(\mathrm{OR}_{\text {adjusted }}=2.25,95 \% \mathrm{Cl}, 1.06-4.77, P=0.04\right.$ for $J A K 2 ; \mathrm{OR}_{\text {adjusted }}=4.33,95 \% \mathrm{Cl}, 2.63-7.13, P<0.01$ for $S T A T 1 ; \mathrm{OR}_{\text {adjusted }}=4.30,95 \% \mathrm{Cl}, 1.38-13.45, P=0.01$ for SOCS3) (Table 3b).

TABLE 3b Associations between the Methylation of Individual Genes and CRC Risk in Groups Stratified by Age 


\begin{tabular}{|c|c|c|c|c|c|c|}
\hline & Genes & & $\begin{array}{l}\text { Cases No. } \\
(\%)\end{array}$ & $\begin{array}{l}\text { Controls No. } \\
(\%)\end{array}$ & $\begin{array}{l}\mathrm{OR}_{\mathrm{ad}} \\
(95 \% \mathrm{CI})\end{array}$ & $P$ value \\
\hline \multirow[t]{8}{*}{$<60$} & $J A K 2$ & Negative & $144(90.0 \%)$ & 168(93.3\%) & Ref & \\
\hline & & Positive & $16(10.0 \%)$ & $12(6.7 \%)$ & $1.82(0.79-4.18)$ & 0.16 \\
\hline & STAT1 & Negative & $63(40.1 \%)$ & $163(78.7 \%)$ & Ref & \\
\hline & & Positive & $94(59.9 \%)$ & $44(21.3 \%)$ & $7.19(4.18-12.37)$ & $<0.01$ \\
\hline & STAT3 & Negative & $136(90.1 \%)$ & 187(91.7\%) & Ref & \\
\hline & & Positive & $15(9.0 \%)$ & $17(8.3 \%)$ & $1.05(0.48-2.28)$ & 0.90 \\
\hline & SOCS3 & Negative & $6(3.9 \%)$ & $20(10.3 \%)$ & Ref & \\
\hline & & Positive & 148(96.1 \%) & 174(89.7\%) & $2.78(1.05-7.34)$ & 0.04 \\
\hline \multirow[t]{8}{*}{$\geq 60$} & $J A K 2$ & Negative & 138(84.1\%) & $155(91.7 \%)$ & Ref & \\
\hline & & Positive & $26(15.9 \%)$ & $14(8.3 \%)$ & $2.25(1.06-4.77)$ & 0.04 \\
\hline & STAT1 & Negative & $58(35.4 \%)$ & $132(72.5 \%)$ & Ref & \\
\hline & & Positive & $106(64.6 \%)$ & $50(27.5 \%)$ & $4.33(2.63-7.13)$ & $<0.01$ \\
\hline & STAT3 & Negative & $146(91.3 \%)$ & 163(91.6\%) & Ref & \\
\hline & & Positive & $14(8.8 \%)$ & $15(8.4 \%)$ & $0.97(0.43-2.17)$ & 0.94 \\
\hline & SOCS3 & Negative & $4(2.1 \%)$ & $22(12.2 \%)$ & Ref & \\
\hline & & Positive & $153(97.5 \%)$ & 158(87.8\%) & $4.30(1.38-13.45)$ & 0.01 \\
\hline
\end{tabular}

CI: confidence interval; CRC: colorectal cancer; OR: odds ratio.

$\mathrm{OR}_{\mathrm{ad}}$ adjusted for gender, BMI, education and occupation

\section{Interaction between Methylation of Genes and Environmental Factors}

Evaluation of the effects of interactions and combinations between gene methylation and environmental factors revealed a significant antagonistic interactive effect between low levels of coarse grain intake ( $<50 \mathrm{~g} /$ week) and the methylation of $J A K 2\left(\mathrm{OR}_{\mathrm{i}}=0.31,95 \% \mathrm{Cl}, 0.11-0.87, P=0.04\right)$ on the risk of CRC.

Antagonistic interactive effects were observed between alcohol consumption $\left(\mathrm{OR}_{\mathrm{i}}=0.33,95 \% \mathrm{Cl}, 0.13\right.$ $0.83, P=0.02)$, smoking $\left(\mathrm{OR}_{\mathrm{i}}=0.46,95 \% \mathrm{Cl}, 0.22-0.94, P=0.03\right)$ and the methylation of STAT1 on the risk of CRC. A high level of MCSM and bean (except soybean) intake ( $\geq 4$ times/week) also showed an antagonistic interactive effect on $\mathrm{CRC}$ risk $\left(\mathrm{OR}_{\mathrm{i}}=0.26,95 \% \mathrm{Cl}, 0.11-0.59, P<0.01\right)$. The details are shown in Table 4. However, the interaction between SOCS3 methylation and environmental factors on the risk of CRC was not assessed, because the frequency of negative methylation in cases was less than $5 \%$ (only $3.38 \%$ ) to lead to unstable results for the effects of interactions and combinations.

TABLE 4 Combined and Interactive Effects between the Methylation of Individual Genes and Environmental

Factors on CRC Risk 


\begin{tabular}{|c|c|c|c|c|c|}
\hline \multirow[t]{3}{*}{ Gene } & & \multicolumn{4}{|c|}{ Coarse Grains Intake (50g/week) } \\
\hline & & $\geq 50$ & $<50$ & Interact & \\
\hline & & $\mathrm{OR}_{\mathrm{eg}}(95 \% \mathrm{CI})$ & & $\mathrm{OR}_{\mathrm{i}}(95 \% \mathrm{CI})$ & $P$ value \\
\hline \multirow[t]{5}{*}{$J A K 2$} & Negative & Ref & $1.81(1.31-2.50)$ & & \\
\hline & Positive & $3.05(1.52-6.13)$ & $1.70(0.78-3.68)$ & $0.31(0.11-0.87)$ & 0.04 \\
\hline & & \multicolumn{4}{|c|}{ Smoking } \\
\hline & & $\mathrm{OR}_{\mathrm{Or}}(95 \% \mathrm{CI})$ & Yes & \multicolumn{2}{|c|}{ Interaction } \\
\hline & & $\mathrm{OR}_{\mathrm{eg}}(95 \% \mathrm{CI})$ & & $\mathrm{OR}_{\mathrm{i}}(95 \% \mathrm{CI})$ & $P$ value \\
\hline \multirow[t]{10}{*}{ STAT1 } & Negative & Ref & $2.45(1.51-3.96)$ & & \\
\hline & Positive & $8.16(4.86-13.70)$ & $9.13(5.25-15.86)$ & $0.46(0.22-0.94)$ & 0.03 \\
\hline & & \multicolumn{4}{|c|}{ Alcohol Intake } \\
\hline & & OR $\quad$ (95\% & Yes & \multicolumn{2}{|c|}{ Interaction } \\
\hline & & \multicolumn{2}{|l|}{$\mathrm{OR}_{\mathrm{eg}}(95 \% \mathrm{CI})$} & $\mathrm{OR}_{\mathrm{i}}(95 \% \mathrm{CI})$ & $P$ value \\
\hline & Negative & Ref & $1.60(0.86-2.99)$ & & \\
\hline & \multirow[t]{3}{*}{ Positive } & $16.51(8.60-31.96)$ & $8.67(4.24-17.74)$ & $0.33(0.13-0.83)$ & 0.02 \\
\hline & & \multicolumn{4}{|c|}{ Bean (except soybean) Intake (average times/week) } \\
\hline & & \multirow{2}{*}{$\begin{array}{l}<4 \\
\mathrm{OR}_{\mathrm{eg}}(95 \% \mathrm{CI})\end{array}$} & \multirow[t]{2}{*}{$\geq 4$} & \multicolumn{2}{|c|}{ Interaction } \\
\hline & & & & $\mathrm{OR}_{\mathrm{i}}(95 \% \mathrm{CI})$ & $P$ value \\
\hline \multirow[t]{2}{*}{ MCSM } & 1 Low level & Ref & $1.20(0.66-2.20)$ & & \\
\hline & High level & $9.41(5.35-16.55)$ & $2.94(1.67-5.17)$ & $0.26(0.11-0.59)$ & $<0.01$ \\
\hline
\end{tabular}

Additionally, significant combination effects between JAK2, STAT1, STAT3, and MCSM methylation and nine environmental factors on CRC risk existed, and the data are shown in Supplemental Tables S1-S9.

\section{Discussion}

Current studies of the association between DNA methylation and CRC risk mostly focus on tumor tissues. Meanwhile, the occurrence and development of tumors is not an isolated event nor does it occur only in one specific organ or system. Tumorigenesis involves numerous changes at the molecular level, affecting not only specific target organs and tissues surrounding the tumor but also other tissues, organs and systems of the body, including the circulatory system. As a closed transport system, the circulatory system not only circulates blood cells but also immune cells that coordinate the function of the whole body, and we considered that the DNA methylation status of the CpG islands in blood cells might represent biomarkers for early tumor detection. Some studies of bladder cancer[19], breast cancer[20], ovarian cancer[21] and small cell lung cancer[22] observed an association between aberrant DNA methylation in peripheral blood and cancer risk, and individual differences in gene methylation can reflect an individual's susceptibility to tumors. In addition, methylation of $\mathrm{CpG}$ islands in genes involved in the JAK-STAT pathway in different tissues was associated with various cancers, including gastric cancer, esophageal cancer, hepatocellular carcinoma, acute leukemia and lung cancer, among others[23-27]. 
Available articles investigating DNA methylation of JAK-STAT pathway-related genes and colorectal cancer risk only examined tissues[28-30].

Our study is the first to identify a significant association between leukocyte-derived DNA methylation on CpG islands in JAK2, STAT1, and SOCS3 and CRC risk. Meanwhile, as an external validation method, we analyzed the data from 588 participants (166 patients and 422 controls) in the EPIC-Italy cohort study GSE51032 performed at the Human Genetics Foundation (HuGeF) in Turin, Italy. The methylation status of $\mathrm{CpG}$ sites located in the closest proximity to the amplified fragment of each gene in leukocyte-derived DNA was assessed. We divided the methylation data into the hypomethylation group and hypermethylation group based on median values. Methylation at cg11065262 of STAT1 showed a significant association with $\mathrm{CRC}$ risk $(\mathrm{OR}=1.50,95 \% \mathrm{Cl}, 1.04-2.15, \mathrm{P}=0.03)$, and this result was consistent with our findings. However, similar results for methylation of the $\mathrm{CpG}$ sites in JAK2, STAT3 and SOCS3 were not obtained, and the details are shown in Table 5. Likewise, the association between an average methylation status of transcription start sites of the four genes and CRC risk was analyzed. Methylation of JAK2 decreased the CRC risk by $40 \%$, which contradicted our results. However, methylation of the other three genes was not associated with the CRC risk. The details are presented in Table S10.

TABLE 5 Association between Loci Methylation of Four Genes and CRC Risk in the GSE51032 Dataset from GEO

\begin{tabular}{lccc}
\hline Gene & Taqman Probe & $\mathrm{OR}_{\mathrm{i}}(95 \% \mathrm{CI})$ & $P$ value \\
\hline JAK2 & cg20394284 & $0.71(0.50-1.03)$ & 0.07 \\
STAT1 & cg11065262 & $1.50(1.04-2.15)$ & 0.03 \\
STAT3 & cg09804439 & $1.31(0.91-1.88)$ & 0.14 \\
SOCS3 & cg14721618 & $1.03(0.72-1.48)$ & 0.86 \\
\hline
\end{tabular}

In the stratified analysis, males with SOCS3 methylation have a 2.60 -fold higher CRC risk, but a similar result was not observed in females. Hypermethylation of the SOCS3 promoter may be involved in the pathogenesis of prostate cancer, which is an androgen-dependent disease. SOCS3 antagonizes the effects of androgen[31]. We speculated that a similar mechanism was employed in CRC development and progression.

Environmental factors have various potential impacts on cancer initiation and progression, and because environmental factors might influence DNA methylation and demethylation activity, we explored the interactive effects between gene methylation and dietary/behavioral factors on the risk of CRC. In the present study, significant antagonistic interactive effects between MCSM and high frequency intake of beans (except soybean) on the risk of CRC were observed. As shown in the study by Bawadi HA et al, black bean condensed tannins dose-dependently inhibited Caco-2 colon, MCF-7 and Hs578T breast, and DU 145 prostatic cancer cell proliferation[32]. Our research revealed an interaction between methylation of STAT1 and smoking that exerted an antagonistic effect on the risk of CRC. The migration of DLD-1 and SW480 cells, which were isolated from Dukes' stage B and C human colon adenocarcinoma, respectively, were increased by nicotine treatment in a dose-dependent manner[33]. Likewise, nude mice treated with a 
high dose of nicotine exhibit significant increases in microvessel densities and VEGF expression compared with the tap water-treated and low-dose nicotine-treated groups[34]. A high level of alcohol consumption is related to colorectal cancer through various mechanisms. For example, alcohol increases the expression of monocyte chemoattractant protein-1 and transactivation of epidermal growth factor receptor signaling, which are related to the tumor microenvironment and metastasis[35-38]. Several population-based epidemiological studies have revealed that whole grain consumption reduces the risk of $\mathrm{CRC}[39-44]$, but the specific molecular mechanism remains unclear. We observed antagonistic effects between JAK2 methylation and low levels of coarse grain intake on the risk of CRC. Further research is needed to explore its causes. Fried foods produce heterocyclic aromatic amines, which has been verified as carcinogens[45]. The study by Amit $\mathrm{D}$ et al did not observe a statistically significant correlation between the consumption of fried meat in a range of 50-210 kcal/day and CRC risk; however, when consumption exceeded $210 \mathrm{kcal} /$ day, the result was statistically significant[46]. However, in our study, and interactive effect was not observed between gene methylation and intake of fried food $\geq 1$ times/week. Vegetables are rich in folate and fiber. Folate is a micronutrient that regulates DNA biosynthesis, repair and methylation to maintain genomic stability. Fiber inhibits cell proliferation and induces apoptosis[47-50]. Interactive effects between gene methylation and the intake of vegetables $\geq 250 \mathrm{~g} /$ day were not observed in our study. The responses of different individuals regarding the intake of various food ingredients and the different cooking methods are complicated; thus, the definite interaction between gene methylation and dietary habits require further exploration in the future.

Our study had several limitations. First, the retrospective survey was limited by inevitable recall bias on dietary and lifestyle habits, even if the experienced investigators tried their best to avoid these sources of bias. Second, we only explored four genes in the JAK-STAT pathway as the key genes. However, if more genes were investigated, we might discuss a comprehensive status and methylation interaction among genes in this pathway. Next, we failed to test the methylation status of the four genes in all subjects because of insufficient DNA concentrations, resulting in the small sample size in the MCSM analysis. Finally, during data analysis, the questionnaire about dietary habits was recorded dichotomously, leading to obscure data regarding dietary factors, which may have impacted the reported interactions between gene methylation and environmental factors.

In conclusion, the methylation status of JAK-STAT pathway-related genes in leukocytes may be a promising biomarker to predict the susceptibility to CRC. The interaction of gene methylation and environmental factors may influence CRC initiation and development, but the precise mechanism requires further research.

\section{Abbreviations}

JAK-STAT, Janus Kinase-signal Transducer and Activator of Transcription; CRC, Colorectal Cancer; MSHRM, Methylation-sensitive High-resolution Melting; JAK, Janus Kinase; STAT, Signal Transducer and Activator of Transcription; SOCS, Suppressors of Cytokine Signaling; PCR, Polymerase Chain Reaction; 
OR, Odd Ratio; 95\% Cl, 95\% Confidence Interval; BMI, Body Mass Index; CpG, Cytosine-phosphate-guanine; MCSM, Multiple CpG Site Methylation.

\section{Declarations}

\section{Ethics approval and consent to participate}

The current study was approved by the Ethics Committee of Harbin Medical University. All the participants provided informed consent before blood collection and the survey.

\section{Consent for publication}

Not applicable.

\section{Availability of data and materials}

The datasets during the current study are available from the corresponding author on reasonable request.

\section{Competing Interests}

The authors have declared that no conflict of interest exists.

\section{Funding}

This study was funded by grants from the Youth Innovative Talents Training Program in Ordinary Universities of the Education Department of Heilongjiang Province (UNPYSCT-2017049); the General Financial Grant of the China Postdoctoral Science Foundation (2015M571446); and Basic Research Projects of Education Department of Heilongjiang Province (2016-KYYWF-0960).

\section{Authors' contributions}

LZ, JR and YZ conceived of and designed the study, directed its implementation, including quality assurance and control, and reviewed the manuscript. RP, HS and YL did the experiments. RP did the data analysis and wrote the manuscript. TT and HB performed the literature search. TX, LZ and YZ helped the study's analytic strategy. All authors read and approved the final manuscript.

\section{Acknowledgements}

Not applicable

\section{Author information}

\section{Affiliations}

Department of Epidemiology, Public Health College, Harbin Medical University, 157 Baojian Street, Nangang District, Harbin, 150081, China. 
Rui Pu, Hongrui Sun, Yupeng Liu, Tian Tian, Haoran Bi, Tingting Xia, Lei Zhang, Yuanyuan Zhang, Lin Zhu and Yashuang Zhao

Second Department of Surgery, The Second Affiliated Hospital of Harbin Medical University, 148 Baojian Street, Nangang District, Harbin, 150081, China.

Jiesheng Rong

Corresponding authors

Correspondence to Lin Zhu, YaShuang Zhao and Jiesheng Rong.

\section{References}

1. Bray F, Ferlay J, Soerjomataram I, Siegel RL, Torre LA, Jemal A: Global cancer statistics 2018: GLOBOCAN estimates of incidence and mortality worldwide for 36 cancers in 185 countries. $C A$ Cancer J Clin 2018, 68(6):394-424.

2. Lao VV, Grady WM: Epigenetics and colorectal cancer. Nat Rev Gastroenterol Hepatol2011, 8(12):686-700.

3. Harrison S, Benziger $\mathrm{H}$ : The molecular biology of colorectal carcinoma and its implications: a review. Surgeon 2011, 9(4):200-210.

4. Bariol C, Suter C, Cheong K, Ku SL, Meagher A, Hawkins N, Ward R: The relationship between hypomethylation and CpG island methylation in colorectal neoplasia. Am J Pathol 2003, 162(4):1361-1371.

5. Villarino AV, Kanno Y, Ferdinand JR, O'Shea JJ: Mechanisms of Jak/STAT signaling in immunity and disease. Journal of immunology (Baltimore, Md : 1950) 2015, 194(1):21-27.

6. Rawlings JS, Rosler KM, Harrison DA: The JAK/STAT signaling pathway. J Cell Sci 2004, 117(Pt 8):1281-1283.

7. Corvinus FM, Orth C, Moriggl R, Tsareva SA, Wagner S, Pfitzner EB, Baus D, Kaufmann R, Huber LA, Zatloukal $\mathrm{K}$ et al: Persistent STAT3 activation in colon cancer is associated with enhanced cell proliferation and tumor growth. Neoplasia 2005, 7(6):545-555.

8. Ma XT, Wang S, Ye YJ, Du RY, Cui ZR, Somsouk M: Constitutive activation of Stat3 signaling pathway in human colorectal carcinoma. World J Gastroenterol 2004, 10(11):1569-1573.

9. Xiong H, Zhang Z-G, Tian X-Q, Sun D-F, Liang Q-C, Zhang Y-J, Lu R, Chen Y-X, Fang J-Y: Inhibition of JAK1, 2/STAT3 Signaling Induces Apoptosis, Cell Cycle Arrest, and Reduces Tumor Cell Invasion in Colorectal Cancer Cells. Neoplasia 2008, 10(3):287-297.

10. Lassmann S, Schuster I, Walch A, Gobel H, Jutting U, Makowiec F, Hopt U, Werner M: STAT3 mRNA and protein expression in colorectal cancer: effects on STAT3-inducible targets linked to cell survival and proliferation. J Clin Pathol 2007, 60(2):173-179. 
11. Lin Q, Lai R, Chirieac LR, Li C, Thomazy VA, Grammatikakis I, Rassidakis GZ, Zhang W, Fujio Y, Kunisada $\mathrm{K}$ et al: Constitutive activation of JAK3/STAT3 in colon carcinoma tumors and cell lines: inhibition of JAK3/STAT3 signaling induces apoptosis and cell cycle arrest of colon carcinoma cells. Am J Pathol 2005, 167(4):969-980.

12. Du W, Hong J, Wang YC, Zhang YJ, Wang P, Su WY, Lin YW, Lu R, Zou WP, Xiong H et al: Inhibition of JAK2/STAT3 signalling induces colorectal cancer cell apoptosis via mitochondrial pathway. J Cell Mol Med 2012, 16(8):1878-1888.

13. Gordziel C, Bratsch J, Moriggl R, Knosel T, Friedrich K: Both STAT1 and STAT3 are favourable prognostic determinants in colorectal carcinoma. Br J Cancer 2013, 109(1):138-146.

14. Boosani CS, Agrawal DK: Methylation and microRNA-mediated epigenetic regulation of SOCS3. Mol Biol Rep 2015, 42(4):853-872.

15. Letellier E, Schmitz M, Baig K, Beaume N, Schwartz C, Frasquilho S, Antunes L, Marcon N, Nazarov $\mathrm{PV}$, Vallar $\mathrm{L}$ et al: Identification of SOCS2 and SOCS6 as biomarkers in human colorectal cancer. $\mathrm{Br} J$ Cancer 2014, 111(4):726-735.

16. Slattery ML, Lundgreen A: The influence of the CHIEF pathway on colorectal cancer-specific mortality. PLoS One 2014, 9(12):e116169.

17. Bock J, Appenzeller S, Haertle L, Schneider T, Gehrig A, Schroder J, Rost S, Wolf B, Bartram CR, Sutter $C$ et al: Single CpG hypermethylation, allele methylation errors, and decreased expression of multiple tumor suppressor genes in normal body cells of mutation-negative early-onset and high-risk breast cancer patients. Int J Cancer 2018, 143(6):1416-1425.

18. Menigatti M, Truninger K, Gebbers JO, Marbet U, Marra G, Schar P: Normal colorectal mucosa exhibits sex- and segment-specific susceptibility to DNA methylation at the hMLH1 and MGMT promoters. Oncogene 2009, 28(6):899-909.

19. Marsit CJ, Koestler DC, Christensen BC, Karagas MR, Houseman EA, Kelsey KT: DNA methylation array analysis identifies profiles of blood-derived DNA methylation associated with bladder cancer. $J$ Clin Oncol 2011, 29(9):1133-1139.

20. Iwamoto T, Yamamoto N, Taguchi T, Tamaki Y, Noguchi S: BRCA1 promoter methylation in peripheral blood cells is associated with increased risk of breast cancer with BRCA1 promoter methylation. Breast Cancer Res Treat 2011, 129(1):69-77.

21. Bosviel R, Michard E, Lavediaux G, Kwiatkowski F, Bignon YJ, Bernard-Gallon DJ: Peripheral blood DNA methylation detected in the BRCA1 or BRCA2 promoter for sporadic ovarian cancer patients and controls. Clin Chim Acta 2011, 412(15-16):1472-1475.

22. Wang L, Aakre JA, Jiang R, Marks RS, Wu Y, Chen J, Thibodeau SN, Pankratz VS, Yang P: Methylation markers for small cell lung cancer in peripheral blood leukocyte DNA. J Thorac Oncol 2010, 5(6):778785.

23. Calvisi DF, Ladu S, Gorden A, Farina M, Conner EA, Lee JS, Factor VM, Thorgeirsson SS: Ubiquitous Activation of Ras and Jak/Stat Pathways in Human HCC. Gastroenterology 2006, 130(4):1117-1128. 
24. Chim CS, Wong AS, Kwong YL: Epigenetic dysregulation of the Jak/STAT pathway by frequent aberrant methylation of SHP1 but not SOCS1 in acute leukaemias. Ann Hematol 2004, 83(8):527532.

25. He B, You L, Uematsu K, Zang K, Xu Z, Lee AY, Costello JF, McCormick F, Jablons DM: SOCS-3 is frequently silenced by hypermethylation and suppresses cell growth in human lung cancer. Proc NatI Acad Sci U S A 2003, 100(24):14133-14138.

26. Hussain S, Singh N, Salam I, Bandil K, Yuvaraj M, Akbar Bhat M, Muzaffar Mir M, Siddiqi MA, Sobti $\mathrm{RC}$, Bharadwaj $\mathrm{M}$ et al: Methylation-mediated gene silencing of suppressor of cytokine signaling-1 (SOCS-1) gene in esophageal squamous cell carcinoma patients of Kashmir valley. J Recept Signal Transduct Res 2011, 31(2):147-156.

27. Oshimo Y, Kuraoka K, Nakayama H, Kitadai Y, Yoshida K, Chayama K, Yasui W: Epigenetic inactivation of SOCS-1 by $\mathrm{CpG}$ island hypermethylation in human gastric carcinoma. Int $\mathrm{J}$ Cancer 2004, 112(6):1003-1009.

28. Fujitake S, Hibi K, Okochi O, Kodera Y, Ito K, Akiyama S, Nakao A: Aberrant methylation of SOCS-1 was observed in younger colorectal cancer patients. Journal of Gastroenterology 2004, 39(2):120124.

29. Kang XC, Chen ML, Yang F, Gao BQ, Yang QH, Zheng WW, Hao S: Promoter methylation and expression of SOCS-1 affect clinical outcome and epithelial-mesenchymal transition in colorectal cancer. Biomed Pharmacother 2016, 80:23-29.

30. Lin SY, Yeh KT, Chen WT, Chen HC, Chen ST, Chiou HY, Chang JG: Promoter CpG methylation of tumor suppressor genes in colorectal cancer and its relationship to clinical features. Oncol Rep 2004, 11(2):341-348.

31. Pierconti F, Martini M, Pinto F, Cenci T, Capodimonti S, Calarco A, Bassi PF, Larocca LM: Epigenetic silencing of SOCS3 identifies a subset of prostate cancer with an aggressive behavior. Prostate 2011, 71(3):318-325.

32. Bawadi HA, Bansode RR, Trappey A, 2nd, Truax RE, Losso JN: Inhibition of Caco-2 colon, MCF-7 and Hs $578 \mathrm{~T}$ breast, and DU 145 prostatic cancer cell proliferation by water-soluble black bean condensed tannins. Cancer Lett 2005, 218(2):153-162.

33. Wei PL, Kuo LJ, Huang MT, Ting WC, Ho YS, Wang W, An J, Chang YJ: Nicotine enhances colon cancer cell migration by induction of fibronectin. Ann Surg Oncol 2011, 18(6):1782-1790.

34. Wong HP, Yu L, Lam EK, Tai EK, Wu WK, Cho CH: Nicotine promotes colon tumor growth and angiogenesis through beta-adrenergic activation. Toxicol Sci 2007, 97(2):279-287.

35. Forsyth CB, Tang Y, Shaikh M, Zhang L, Keshavarzian A: Alcohol stimulates activation of Snail, epidermal growth factor receptor signaling, and biomarkers of epithelial-mesenchymal transition in colon and breast cancer cells. Alcohol Clin Exp Res 2010, 34(1):19-31.

36. Phipps Al, Shi Q, Limburg PJ, Nelson GD, Sargent DJ, Sinicrope FA, Chan E, Gill S, Goldberg RM, Kahlenberg $\mathrm{M}$ et al: Alcohol consumption and colon cancer prognosis among participants in north central cancer treatment group phase III trial N0147. Int J Cancer 2016, 139(5):986-995. 
37. Summa KC, Jiang P, Fitzpatrick K, Voigt RM, Bowers SJ, Forsyth CB, Vitaterna MH, Keshavarzian A, Turek FW: Chronic Alcohol Exposure and the Circadian Clock Mutation Exert Tissue-Specific Effects on Gene Expression in Mouse Hippocampus, Liver, and Proximal Colon. Alcohol Clin Exp Res 2015, 39(10):1917-1929.

38. Xu M, Wang S, Qi Y, Chen L, Frank JA, Yang XH, Zhang Z, Shi X, Luo J: Role of MCP-1 in alcoholinduced aggressiveness of colorectal cancer cells. Mol Carcinog 2016, 55(5):1002-1011.

39. Chatenoud L, Tavani A, La Vecchia C, Jacobs DR, Jr., Negri E, Levi F, Franceschi S: Whole grain food intake and cancer risk. Int J Cancer 1998, 77(1):24-28.

40. Haas P, Machado MJ, Anton AA, Silva AS, de Francisco A: Effectiveness of whole grain consumption in the prevention of colorectal cancer: meta-analysis of cohort studies. Int J Food Sci Nutr 2009, 60 Suppl 6:1-13.

41. Kyro C, Olsen A, Landberg R, Skeie G, Loft S, Aman P, Leenders M, Dik VK, Siersema PD, Pischon T et al: Plasma alkylresorcinols, biomarkers of whole-grain wheat and rye intake, and incidence of colorectal cancer. J Natl Cancer Inst 2014, 106(1):djt352.

42. Larsson SC, Giovannucci E, Bergkvist L, Wolk A: Whole grain consumption and risk of colorectal cancer: a population-based cohort of 60,000 women. Br J Cancer 2005, 92(9):1803-1807.

43. Schatzkin A, Mouw T, Park Y, Subar AF, Kipnis V, Hollenbeck A, Leitzmann MF, Thompson FE: Dietary fiber and whole-grain consumption in relation to colorectal cancer in the NIH-AARP Diet and Health Study. Am J Clin Nutr 2007, 85(5):1353-1360.

44. Song M, Garrett WS, Chan AT: Nutrients, foods, and colorectal cancer prevention. Gastroenterology 2015, 148(6):1244-1260 e1216.

45. Reistad R, Rossland OJ, Latva-Kala KJ, Rasmussen T, Vikse R, Becher G, Alexander J: Heterocyclic aromatic amines in human urine following a fried meat meal. Food Chem Toxicol 1997, 35(1011):945-955.

46. Joshi AD, Kim A, Lewinger JP, Ulrich CM, Potter JD, Cotterchio M, Le Marchand L, Stern MC: Meat intake, cooking methods, dietary carcinogens, and colorectal cancer risk: findings from the Colorectal Cancer Family Registry. Cancer Med 2015, 4(6):936-952.

47. Ferguson LR, Karunasinghe N, Philpott M: Epigenetic events and protection from colon cancer in New Zealand. Environ Mol Mutagen 2004, 44(1):36-43.

48. Ganesh B, Talole SD, Dikshit R: A case-control study on diet and colorectal cancer from Mumbai, India. Cancer Epidemiol 2009, 33(3-4):189-193.

49. Johnson IT: New approaches to the role of diet in the prevention of cancers of the alimentary tract. Mutat Res 2004, 551(1-2):9-28.

50. Ross SA: Diet and DNA methylation interactions in cancer prevention. Ann N Y Acad Sci 2003, 983:197-207.

\section{Supplementary Files}


This is a list of supplementary files associated with this preprint. Click to download.

- supplementary.pdf 